\begin{tabular}{cc|c}
\hline Tar. Bil. Der. & Journal of Agricultural Sciences \\
& $\begin{array}{c}\text { Dergi web sayfası: } \\
\text { www.agri.ankara.edu.tr/dergi }\end{array}$ & Journal homepage: \\
& www.agri.ankara.edu.tr/journal
\end{tabular}

\title{
Assessment of Weed Competition Critical Period in Sugar Beet
}

\author{
Dogan ISIK ${ }^{\mathrm{a}}$, Adem AKCA ${ }^{\mathrm{b}}$ \\ ${ }^{a}$ Erciyes University, Faculty of Agriculture, Department of Plant Protection, Kayseri, TURKEY

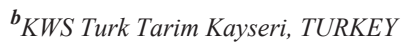

\section{ARTICLE INFO}

Research Article DOI: 10.15832/ankutbd.446394

Corresponding Author: Dogan ISIK, E-mail: dogani@erciyes.edu.tr, Tel: +90 (352) 4371790

Received: 06 November 2015, Received in Revised Form: 08 February 2016, Accepted: 31 May 2016

\begin{abstract}
Weed control constitutes the most essential issue in cropping systems. The critical periods should especially be determined for each crop. Field experiments were conducted during the seasonal growing periods of sugar beet in 2012 and 2013 in Kayseri, Turkey to assess the critical weed control period (CPWC). A log-logistic model having four parameters was used to assist in monitoring and analyzing two sets of related, relative crop yield. Data was obtained during the periods of increased weed interference and as to compare, during the weed-free periods. In both years, the relative root yield of sugar beet decreased with a longer period of weed-interference and increased where there was a longer weed-free period. In 2012, the CPWC varied between 122-595 GDD (growing degree days) corresponding to 12 to 46 days after crop emergence (DAE). The following year, CPWC were found to be between 82-735 GDD, (8-54 DAE) based on 5\% acceptable yield loss. Weed-free conditions are needed to be arranged as early as the first week after crop emergence and maintained up to and including nine weeks thereafter to avoid more than a 5\% loss in sugar beet root yield. Those results could assist sugar beet producers through reducing the expenses significantly, as well as improving the efficacy of their weed management programs.
\end{abstract}

Keywords: Critical period; Nonlinear regression; Weeds; Competition; Sugar beet

\section{Şeker Pancarında Yabancı Ot Rekabetinde Kritik Periyodun Belirlenmesi}

\section{ESER BILLGISI}

Araştırma Makalesi

Sorumlu Yazar: Dogan ISIK, E-posta: dogani@erciyes.edu.tr, Tel: +90 (352) 4371790

Geliş Tarihi: 06 Kasım 2015, Düzeltmelerin Gelişi: 08 Şubat 2016, Kabul: 31 Mayıs 2016

\section{ÖZET}

Yabancı ot kontrol dönemlerinin doğru olarak belirlenmesi, yabancı ot yönetimi planlarının önemli kıstaslarından birisidir. Şeker pancarında yabancı ot mücadelesinde kritik periyodun belirlenmesi amaciyla 2012 ve 2013 yıllarında Kayseri'de tarla denemeleri yürütülmüştür. İki set halindeki oransal verimin analizinde dört parametreli log-lojistik model kullanılmıştır. Veriler başlangıcı yabancı otlu ve başlangıcı yabancı otsuz olarak oluşturulan parsellerden elde edilmiştir. Her iki yılda da şeker pancarı verimi yabancı otlu kalma süresi arttıkça azalırken, yabancı otsuz kalma süresi arttıkça da artmıştır. \% 5 kabul edilebilir verim kaybı seviyesinde 2012 yılında yabancı ot mücadelesinde kritik periyot 
ürün çıkışından sonraki 12-46. günlere karşılık gelen 122 ila 595 GGD (gelişme gün derece) arasında değişmiştir. 2013 yılında ise 82-735 GGD olmuştur (çıkıştan sonraki 8 ile 54. günler). \% 5 ’ten fazla ürün kaybını engellemek için, ürün çıkışından sonra ilk haftadan başlayarak 9. haftaya kadar ürünün yabancı otsuz tutulması gerekli olduğu belirlenmiştir. Bu sonuçlar şeker pancarı üreticilerinin giderlerini önemli ölçüde azaltmanın yanı sıra yabancı ot yönetim programlarının etkinliğinin artırılmasına da yardımcı olabilecek niteliktedir.

Anahtar Kelimeler: Kritik periyot; Doğrusal olmayan regresyon; Yabancı ot; Rekabet; Şeker pancarı

\section{Introduction}

Sugar is produced from sugar beet (Beta vulgaris L.) in Turkey as it was in majority of Europe because of climate conditions. Sugar beet prefer climates with warm days and cool nights. Thus, Central Anatolia is a favorable region for sugar beet culture. Irrigation is applied in sugar beet culture of Turkey and production is performed under a contract with a sugar company (Kiymaz \& Ertek 2015). Recent annual world sugar beet production is around 247 million tons from 4.4 million hectares (FAO 2015). Sugar beets are primarily produced in France, United States, Germany, Russian Federation, Turkey, Poland, Ukraine, United Kingdom, and China (FAO 2015).

Ever-increasing world population and industrial developments always keep sugar production in the agenda of world countries. The primary goal of sugar beet producers is to achieve high yields and quality (Bakhshkandi et al 2013). Weeds are one of the major concerns in sugar beet culture. Sugar beet is extremely sensitive to weed competition during the initial growth stages, so effective weed control is critical at this stage (Jalali \& Salehi 2013; Marwitz et al 2014). The presence of weeds can decrease sugar beet yield by $90 \%$. While this yield loss is $45 \%$ in Asian countries, it is between 6-40\% in Turkey (Güncan 2000). For example, a single barnyard grass (Echinochloa crus-galli (L.) Beauv.) per 1.5 $\mathrm{m}^{2}$ can reduce the yields around $5-15 \%$ (Norris 1996). To eliminate the damage caused by weeds or at least to reduce, weed control in agricultural fields are paid more attention. Such a case then leads labor requirements and great financial losses. Therefore, new methods are developed in time in order to identify the best weed control timing and to minimize costs (Malasl1 2010).

In Turkey, standard design procedures incorporate herbicides into weed control practices and cultivation is implemented strategically to manage weeds. Weed control essentially is done at the beginning of the growing season since young, newly emerged sugar beets are highly susceptible to weed competition at this critical stage. In fact, even before this stage, at the pre-sowing or before plant emergence, herbicides sprays are habitually applied for weed control in sugar beet fields. Following plant emergence, on the other hand, hoeing (either with machines or manual) is done for weed control (Jalali \& Salehi 2013; Marwitz et al 2014).

For a successful integrated weed management (IWM), some key issues like the effect of control practices on weeds, growth and development stages of weed population and critical periods for applications should be taken into consideration (Young 2012). The criteria for critical period of weed control (CPWC) provide essential guidance on relevant time periods and growth stages during which crops ideally should be kept free of weeds to stop yield or quality reductions by weed interference (Evans et al 2003). Two separate weed interference scenarios are defined as; 1) the longest possible period from the time that crops are planted or from the time that the crops can live together side by side with the weeds without unreasonable yield loss (critical weed interfering period) and 2) the possible shortest period for crop to be retained weed-free prior to yield reduction effected by weed growth is no longer a problem (the critical weed-free period) (Evans et al 2003). Thus, the CPWC identifies the 
most beneficial time periods for the best IWM program (Swanton \& Weise 1991).

Weed-crop competition critical periods in sugar beet have been monitored and statistically analyzed only in a few environments and only for a limited variety of weed types. Sugar beet can tolerate weeds until 2-8 weeks after emergence, depending on the weeds, date of planting, weed emergence time and ecological factors (Salehi et al 2006). Irrigated sugar beet should be free from weeds for 10 to 12 weeks after planting, thereafter it could compete with weeds until the end of season and those weeds emerging later would be suppressed by sugar beet (Dawson 1977). Salehi et al (2006) carried out a study to identify the beginning and end of CPWC in sugar beet and identified the beginning of critical period as 25 days thereafter sowing for the first year and 4 days thereafter sowing for the following year; the end of critical period was identified as 78 days after sowing for the first year and 88 days thereafter sowing in the following year. The principle idea of this research was to determine the CPWC for sugar beet grown in Central Anatolian Region of Turkey, an area where there is little or no apparent knowledge on CPWC.

\section{Material and Methods}

\subsection{Site description}

Trials were carried out in 2012 and 2013 on arable lands of Yeşilhisar, Kayseri in Central Anatolian region of Turkey. The soil texture of the experimental site was clay with $\mathrm{pH}$ of 7.92 , EC of $0.08 \mathrm{mS} \mathrm{cm}^{-1}$, lime content of $20.19 \%$ and organic matter content of $1.24 \%$. Available P and $\mathrm{K}$ concentrations of soil were 21.94 and $1390 \mathrm{~kg} \mathrm{ha}^{-1}$, respectively.

\subsection{Experimental design}

Experimental analyses were undertaken in accordance with local practices of the region. Initial tillage comprised of chisel plowing in spring and subsequent disking with a harrow. In general, pre-emergence and post-emergence herbicides are utilized in the region for weed control of sugar beet. In this study, however, weeding was done by hand hoeing. Valentina sugar beet cultivar was sown on $12 \mathrm{~cm}$ lines over rows $45 \mathrm{~cm}$ apart. The plots were fertilized in two stages. Initially, $500 \mathrm{~kg} \mathrm{ha}^{-1}$ of compound fertilizers (13-24-12) were spread over the plots at the time of sowing. Then, the remaining fertilizers were spread over the plots in two parts with $300 \mathrm{~kg}$ of ammonium sulfate (AS) (21-0-024S) $\mathrm{ha}^{-1}$ and $300 \mathrm{~kg}$ of ammonium nitrate (AN) $\mathrm{ha}^{-1}(33 \% \mathrm{~N})\left(2 \times 300 \mathrm{~kg}=600 \mathrm{~kg} \mathrm{ha}^{-1}\right)$ and then the plants were irrigated. The crops were irrigated ten times during the growing period. The water level for each irrigation was calculated by taking crop water requirement, precipitation and temperature into consideration.

Experiments were designed in randomized blocks with 4 replicates. Two methods of weed interference treatments were used and these were initiated at crop emergence. To assess the start of CPWC, weeds were grown with the crop at 2 week intervals with sugar beet 0 to 12 WAE (week after emergence). To establish the end of a CPWC, plots were completely weeded at biweekly intervals for 0 to 12 WAE with occasional hand hoeing. Weedfree control and untreated weedy control plots were introduced into both parts of the experiment. All plots were 1.8 meters wide, 5 meters long and had four rows. All results were recorded from only the inner two rows of the plots.

\subsection{Weed and crop measurements}

Population density of weeds was determined from an arbitrarily placed $1 \mathrm{x} 1$ meter quadrat. At maturity, the sugar beet harvesting was made by hand from the inner two rows of each plot. Species composition and weed density were assessed through categorizing and counting the weeds from two $0.5 \mathrm{~m}^{2}$ quadrate in each plot. Weeds were cut off from the ground and dried at $70{ }^{\circ} \mathrm{C}$ to determine aboveground dry matter. In both years, final crop harvests were carried out when the sugar beet had reached to full maturity. Samples for sugar beet yield determination from each plot were obtained by hand-harvesting from $4.5 \mathrm{~m}^{2}$ areas of the middle two rows. 


\subsection{Growing degree days (GDDs) calculation}

Total monthly rain fall (mm) and average temperatures $\left({ }^{\circ} \mathrm{C}\right)$ throughout the experiments were recorded from the Yesilhisar Meteorological Station.

GDD values are commonly used as an independent variable for regression analysis and the relevant values were calculated in accordance with Gilmore \& Rogers (1958) (Equation 1). The DAE (days after emergence) was preferred for the reference point for gathering of GDD.

$\mathrm{GDD}=\sum\left[\frac{T_{\max }+T_{\min }}{2}\right]-T_{\mathrm{b}}$

Where; $T_{\max }$ and $T_{\text {min }}$, daily maximum and daily minimum temperatures $\left({ }^{\circ} \mathrm{C}\right)$, respectively; $T_{\mathrm{b}}$, basis temperature $\left({ }^{\circ} \mathrm{C}\right)$. For $T_{\max }$, the values over $30{ }^{\circ} \mathrm{C}$ were assumed as $30^{\circ} \mathrm{C}$ and for $T_{\text {min }}$, the values below $10{ }^{\circ} \mathrm{C}$ were taken as $10{ }^{\circ} \mathrm{C}$. The base temperature was taken as $5^{\circ} \mathrm{C}$ (Parthasarathi et al 2013).

\subsection{Statistical analysis}

Variance analysis (ANOVA) on all measured data was conducted by using $\mathrm{R}$ software ( $\mathrm{R}$ Development Core Team 2006). Differences among years, treatments, replications and interactions were tested at significance level of $\mathrm{P}<0.05$. The relative yield of every plot was recorded as a percentage of the corresponding weed-free yield within each replication for each treatment. Statistical analysis was performed yearly, since the growing degree days were different in both years. Four-parameter log-logistic model were used for relative yield $(\%$ of weed-free). The data was analyzed by fixing the $D$ term to 100 (Knezevic et al 2007) (Equation 2).

$\mathrm{Y}=\frac{C+(D-C)}{\{1+\exp [B(\log X-\log E)]\}}$

Where; $Y$, response (e.g., relative yield); $C$, lower limit; $D$, upper limit; $X$, GDD found after crop emergence; $E$, GDD having a $50 \%$ response between the upper and lower limits (also known as the inflection point, $I_{50}$ ); $B$, slope of the line at the inflection point (the rate of change).
The regression analyses were carried out by using GDD as a quantitative variable because it is an established biological test measurement of time well suited for assessing the progress of growth and development (Gilmore \& Rogers 1958). If one considers the curve fitting procedure, GDD is a more popular variable utilized for fitting regression models as appose to using a categorical parameters [e.g., crop growth stage (CGS)] as GDD ensures a constant and more accurate $\mathrm{x}$-axis scale. It is a better indicator in comparing years and planting dates of different areas (Knezevic et al 2002). In addition, GDD can be used together with specific CGS to allow more expeditious field assessments thus, from a practical point of view; the essential data becomes more readily accessible to farmers, counselors and practitioners (Knezevic et al 2002).

Statistical analyses were carried out and graphs were drawn up with R software exploiting the DRC (dose response curves) statistical add-on package (Knezevic \& Datta 2015). The rate of $\mathrm{YR}_{2.5}(2.5 \%$ yield decrease), $\mathrm{YR}_{5}\left(5 \%\right.$ yield decrease) and $\mathrm{YR}_{10}$ ( $10 \%$ yield decrease) were obtained from the curves yielding an objective range for measuring the effects of increased periods of weed occurrence and weedfree treatments on crop yield. The $2.5 \%, 5 \%$ and $10 \%$ yield decrease were expressed in GDD indicating the impact of the length of weed interference. The estimation of GDD related to $90 \%, 95 \%$ and 97.5\% relative yield was calculated from Equation 2 for each year and then the same was applied for the DAE. In the present study, the greatest yield decrease of 5\% was randomly assigned as the value above which yield decrease was determined as being undesirable (Tursun et al 2012).

\section{Results and Discussion}

\subsection{Weed density and dry matter}

The weed populations were similar in both years (Table 1). The widespread weeds in the experimental area were identified as barnyard grass (Echinochloa crus-galli (L.) Beauv.), European heliotrope (Heliotropium europaeum L.), common lambsquarters (Chenopodium album L.), spear 
saltbush (Atriplex patula L.), round leaf cancer wort (Kickxia spuria L.), and redroot pigweed (Amaranthus retroflexus L.).

Table 1- The weed population densities (plants $\mathbf{m}^{-2}$ ) in the season-long weedy treatment

\begin{tabular}{lll}
\hline \multirow{2}{*}{ Weed species } & \multicolumn{2}{l}{ Density $\left(\right.$ plants m $^{-2}$ ) } \\
\cline { 2 - 3 } & 2012 & 2013 \\
\hline Echinochloa crus-galli L. & 31 & 36 \\
Heliotropium europaeum L. & 14 & 17 \\
Chenopodium album L. & 13 & 16 \\
Atriplex nitens L. & 8 & 11 \\
Kickxi aspuria L. & 9 & 11 \\
Amaranthus retroflexus L. & 8 & 9 \\
Euphorbia spp. & 4 & 8 \\
Anagallis foemina L. & 5 & 8 \\
Chondrilla juncea L. & 5 & 7 \\
Convolvulus arvensis L. & 0.2 & 2 \\
Sonchus arvensis L. & - & 1 \\
Tribulu sterrestris L. & 1 & 0.5 \\
Xanthium strumarium L. & 1 & 0.4 \\
Acroptilon repens L. & 0.4 & 0.2 \\
Sinapis arvensis L. & - & 0.2 \\
Stellaria media L. & 0.3 & - \\
Cuscuta spp. & - & 1 \\
Fumaria parviflora L. & - & 0.25 \\
Alhagi pseudalhagi L. & - & 0.25 \\
Total & 99.9 & 128.8 \\
\hline
\end{tabular}

These six species made up 83 and $78 \%$ of the total weed mass in 2012 and 2013, respectively. All these weeds are common in other summer grown crops in this location as well (Akça \& Isik 2013). Some of these weeds (E. crus-galli, A. retroflexus, C. album, $X$. strumarium, ) were the same type seen and analyzed in earlier studies carried out to find out the CPWC in other types of crops in Turkey (Isik et al 2006; Tursun et al 2012). Such weed species are abundant and important weeds in Turkey.

The total weed dry matter went up as the extent of weed interfering phase increased in the plots. The total dry matter was higher in 2013 than in 2012 (Figure 1, Table 2) and the weed acquisition weight increased more in 2013 than in 2012. These figures were established by assessment of the weed density in 2013 (Table 1). Our results were parallel with the reports of Kropff et al (1992), Salehi et al (2006), Jursik et al (2008) and Mobarak (2013) indicating increased weed biomass with increasing infestation durations.

\subsection{Critical period for weed control}

An interaction was seen between 2012 and 2013 and the treatments stages at the onset and at the end of the CPWC; so, all data of yield was additionally assessed separately for each year (Figure 2, Table 3).

\section{2}

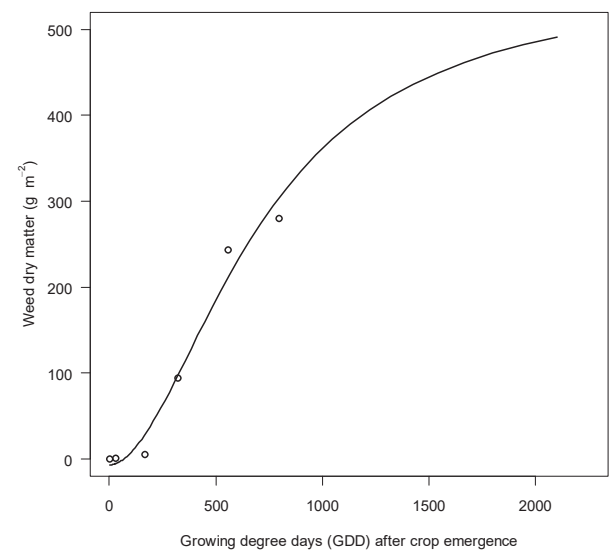

2013

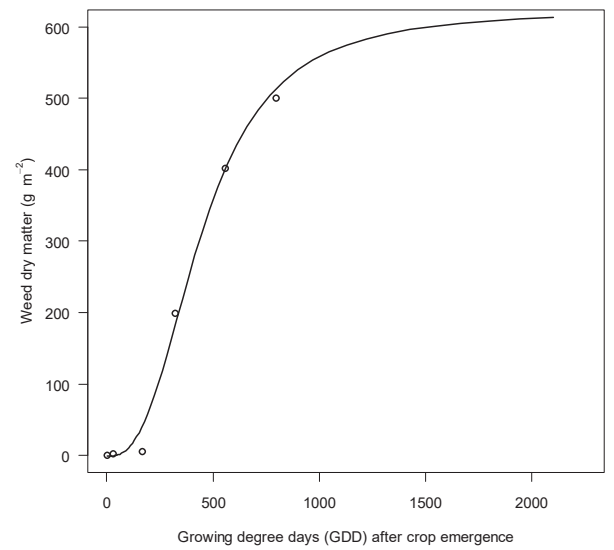

Figure 1- Weed dry biomass $\left(\mathrm{g} \mathrm{m}^{-2}\right)$ response to duration of weed interference, shown by growing degree days (GDD); the regression lines were plotted using Equation 2; parameter values were given in Table 2 
Table 2- Regression parameters $( \pm \mathrm{SE})$ by year and practice for logistic model (Equation 2) describing the effects of weed interfering duration on weed dry biomass $\left(\mathrm{g} \mathrm{m}^{-2}\right)$

\begin{tabular}{ccccc}
\hline \multirow{2}{*}{ Year } & \multicolumn{4}{c}{ Regression parameters $( \pm S E)$} \\
\cline { 2 - 5 } & $B$ & $C$ & $D$ & $I_{50}$ \\
\hline 2012 & $-1.9(0.6)$ & $-6.8(25.7)$ & $557.9(78)$ & $713.5(157.7)$ \\
2013 & $-2.7(0.9)$ & $-1.2(40.3)$ & $622.9(68)$ & $446.0(74.1)$ \\
\hline
\end{tabular}

$B$, slope of the line at the inflection point; $C$, the lower limit; $D$, the upper limit; $I_{50}$, the GDD giving a $50 \%$ response between the upper and the lower limit

The length of weed-interference or weed-free period altered the sugar beet relative root yield (Figure 2). Increasing periods of weed interference noticeably reduced sugar beet root yields in both years. While the average sugar beet root yields from the weed free plots were $123583 \mathrm{~kg} \mathrm{ha}^{-1}$ in 2012 and $125144 \mathrm{~kg}$ $\mathrm{ha}^{-1}$ in 2013; the whole season weed infested plots had root yields of $50027 \mathrm{~kg} \mathrm{ha}^{-1}$ in 2012 and 2276 $\mathrm{kg} \mathrm{ha}^{-1}$ in 2013. These results were again similar with the results of Salehi et al (2006) and Mobarak (2013) reporting lower root yields of sugar beet with rising weed interfering.

The CPWC varied in both years (Figure 2). The extent of the CPWC in sugar beet was 45, 34 and 24 days in 2012 and 60, 46, 32 days in 2013 with $2.5,5$ and $10 \%$ acceptable yield loss levels (AYL), respectively. A 5\% yield loss is accepted as a rule for most crops in Turkey (Isik et al 2006; Tursun et al 2012). Based on 5\% acceptable yield loss (AYL), the beginning of CPWC in sugar beet was identified
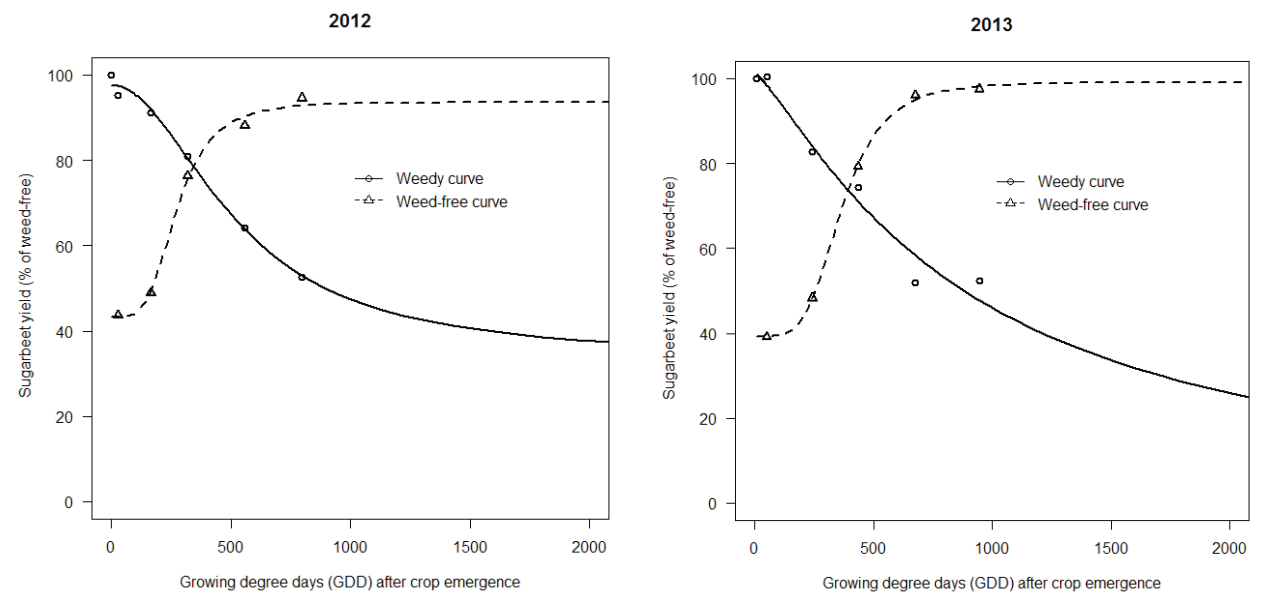

Figure 2- Effect of weed interference on sugar beet root yield (\% of weed-free) as shown by growing degree days (GDD); the regression lines were plotted by using Equation 2; the parameter values were given in Table 3

Table 3- Parameter estimates $( \pm \mathrm{SE})$ by year and application for logistic model (Equation 2) describing the influence of weed interfering duration on the relative yield of sugar beet

\begin{tabular}{llrrrr}
\hline \multirow{2}{*}{ Year } & \multirow{2}{*}{ Treatments } & \multicolumn{4}{c}{ Regression parameters $( \pm$ SE) } \\
\cline { 3 - 6 } & & \multicolumn{1}{c}{$C$} & \multicolumn{1}{c}{$D$} & \multicolumn{1}{c}{$I_{50}$} \\
\hline 2012 & Weedy & $2.0(0.3)$ & $33.7(2.8)$ & $97.6(2.3)$ & $527.1(35.3)$ \\
2012 & Weed-free & $-3.8(1.0)$ & $43.2(2.4)$ & $93.6(2.8)$ & $275.5(19.1)$ \\
2013 & Weedy & $1.2(0.4)$ & $-1.1(29.1)$ & $101.3(4.3)$ & $877.9(456.0)$ \\
2013 & Weed-free & $-4.2(0.4)$ & $39.2(1.2)$ & $99.2(1.3)$ & $366.7(10.1)$ \\
\hline
\end{tabular}

$\mathrm{B}$, slope of the line at the inflection point; $\mathrm{C}$, lower limit; $\mathrm{D}$, upper limit; $\mathrm{I}_{50}$, the GDD giving a $50 \%$ response between the upper and the lower limit 
as 122 GDD in 2012 and 82 GDD in 2013, which corresponds to 8-12 DAE (Table 4). Based on 2.5 and $10 \% \mathrm{AYL}$, onset of the CPWV was identified as between 86-177 GDD in 2012 (8-17 DAE) and as between 46-150 GDD in 2013 (4-15 DAE). The onset of CPWC was the same CGS (V1) in both years (Table 4).

The end of CPWC varied among the years (Figure 2). The end of CPWC in sugar beet was 595 GDD in 2012 and 735 GDD in 2013 corresponding to 46-54 DAE and V4-V5 CGS at 5\% AYL (Table 4). The end of CPWC rose as the AYL decreasing from $10 \%$ to $2.5 \%$ (Figure 2). The differences between the end of CPWC in both years were possibly because of the differences in weed populations between the growing seasons (Table 1) and this might have been due to variations in sowing time and rainfall amounts in each respective years (Tursun et al 2012).

Weeds reduced sugar beet root yields by 60 $82 \%$ when the weed interference was permitted throughout the growing season. Such findings comply with the results of Jursik et al (2008) and Mobarak (2013) indicating decreasing sugar beet root weight for each plant and root yield with increasing duration of weed presence. As stated by Salehi et al (2006) and Mobarak (2013), although sugar content did not show any significant difference between various treatments in both years, weed infestation decreased both root and sugar yields. It was observed that weed interference influenced both total production and quality. Parallel findings were indicated by Bukun (2004) in cotton and Isik et al (2006) in corn.

Present findings indicate that weed control measures in Central Anatolian Region of Turkey begin 4-8 days after sugar beet emergence. At early growth stages, sugar beet has a low competitive ability against weeds; as a result, critical period would start sooner (Salehi et al 2006). Dawson (1977) showed that weeds that germinated in the 2 and 4 weeks period after sugar beet sowing reduced yield between 26 and $100 \%$, respectively. Therefore, effective control of weeds at early stages seems to be more important than that of later growth stages. A previous study indicated that critical weed control periods varied based on emergence periodicity and weed density (Bukun 2004).

Table 4- The critical weed control period (CPWC) for sugar beet highlighted in growing degree days (GDD), related crop growth stage (CGS) and days after crop emergence (DAE)

\begin{tabular}{llrrr}
\hline \multirow{2}{*}{$\begin{array}{l}\text { Year } \\
\text { Yeld reduction }\end{array}$} & \multicolumn{3}{c}{$C P W C$} \\
\cline { 3 - 5 } & & $G D D$ & $C G S$ & DAE \\
\hline The beginning of CPWC & 2.5 & 86 & $\mathrm{~V} 1$ & 8 \\
& 5 & 122 & $\mathrm{~V} 1$ & 12 \\
& 10 & 177 & $\mathrm{~V} 1$ & 17 \\
& & & & \\
2013 & 2.5 & 46 & $\mathrm{~V} 1$ & 4 \\
& 5 & 82 & $\mathrm{~V} 1$ & 8 \\
& 10 & 150 & $\mathrm{~V} 1$ & 15 \\
\hline The end of CPWC & & & & \\
2012 & 2.5 & 718 & $\mathrm{~V} 5$ & 53 \\
& 5 & 595 & $\mathrm{~V} 4$ & 46 \\
& 10 & 489 & $\mathrm{~V} 3$ & 41 \\
2013 & 2.5 & & & \\
& 5 & 871 & $\mathrm{~V} 7$ & 64 \\
& 10 & 735 & $\mathrm{~V} 5$ & 54 \\
& & 616 & $\mathrm{~V} 4$ & 47 \\
\hline
\end{tabular}


In Turkey, herbicide treatments and hoeing are primary methods used in weed control in sugar beet. As a result of early CPWC (1 week AE), producers are able to arrange the herbicide treatment and hoeing periods. Additional experiment should be carried out to find out the CPWC for other locations with different weed types and populations. Widespread information about CPWC in sugar beet could assist decision-makers in correct timing for herbicide application at post-emergence stage of crops. Enhanced knowledge and usage of CPWC would also lead to more effective and efficient ways of weed control. Reduced herbicide use would also reduce the risk of environmental pollution and the stress factors involved in trying to assess the most herbicide-resistant weeds (Hall et al 1992).

\section{Conclusions}

An effective integrated weed management system (IWM) relies on information on behaviors of the weeds and their impacts on yields. The CPWC is an essential issue in formulating strategies for IWM. The level weed interference is also influenced by light, water and plant nutrients. Sugar beet yield is therefore directly related and dependent on its ability to secure as much of these resources as possible throughout the growing season. Weeds should have an insignificant effect on sugar beet yield if they are controlled at the correct time. Based on 5\% AYL figure, the present findings indicated that sugar beet tolerated weed interference up until 8 to 12 days after crop emergence (DAE), therefore it was concluded that weed control practices should be performed right in this period. Plants must be free of weeds until 46 to $54 \mathrm{DAE}$ to prevent yield loss over $5 \%$. Weeds that emerge after 46 to $54 \mathrm{DAE}$ grow in a competition with sugar beet.

\section{Acknowledgements}

Authors thank to Erciyes University BAP Unit for financial assistance (with the project FBA-12-3870) provided to the present research.

\section{References}

Akça A \& Isik D (2013). Determination of weed species in sugar beet field (Beta vulgaris L.) in Kayseri Province in Turkey. In: Proceedings of the $16^{\text {th }}$ EWRS, European Weed Research Society Symposium. 24-27 June, Samsun, Turkey, pp. 132-141

Bakhshkandi H, Mirshekari B, Pedram A \& Alizadeh E (2013). Planting pattern could increase competitive power in sugar beet (Beta vulgaris) cultivars at interference with redroot pigweed (Amaranthus retroflexus). Life Science Journal 10: 185-188

Bukun B (2004). Critical periods for weed control in cotton in Turkey. Weed Research 44: 404-412

Dawson J H (1977). Competition of late emerging weeds with sugar beets. Weed Science 25: 168-170

Evans S P, Knezevic S Z, Lindquist J L, Shapiro C A \& Blankenship E E (2003). Nitrogen application influences the critical period for weed control in corn. Weed Science 51: 408-417

FAO (2015). FAOSTAT Online Database, Available from: http://faostat.fao.org/ (Accessed September, 2015)

Gilmore E C \& Rogers R S (1958). Heat units as a method of measuring maturity in corn. Agronomy Journal 50: 611-615

Güncan A (2000). Şeker pancarlarında ekim öncesi yabanc1 ot mücadelesi. Pancar Ekicileri Eğitim ve Sağlık Vakfı Yayınları No: 5, Ankara, s. 143-148

Hall M R, Swanton C J \& Anderson G W (1992). The critical period of weed control in grain corn (Zea mays). Weed Science 40: 441-447

Isik D, Mennan H, Bukun B, Oz A \& Ngouajio M (2006). The critical period for weed control in corn in Turkey. Weed Technology 20: 867-872

Jalali A H \& Salehi F (2013). Sugar beet yield as affected by seed priming and weed control. Archives of Agronomy and Soil Science 59: 281-288

Jursik M, Holec J, Soukup J \& Venclova V (2008). Competitive relationships between sugar beet and weeds in dependence on time of weed control. Plant, Soil and Environment 54: 108-116

Kiymaz S \& Ertek A (2015). Water use and yield of sugar beet (Beta vulgaris L.) under drip irrigation at different water regimes. Agricultural Water Management 158: 225-234

Knezevic S Z \& Datta A (2015). The critical period for weed control: Revisiting data analysis. Weed Science 63(Special Issue): 188-202 
Knezevic S Z, Evans S P, Blankenship E E, Van Acker R C \& Lindquist J L (2002). Critical period for weed control: The concept and data analysis. Weed Science 50: $773-786$

Knezevic S Z, Streibig J C \& Ritz C (2007). Utilizing $\mathrm{R}$ software package for dose-response studies: The concept and data analysis. Weed Technology 21: 840848

Kropff M J, Spitters C J T, Schneiders B J, Joenije W \& Groot W D E (1992). An ecophysiological model for interspecific competition, applied to the influence of Chenopodium album L. on sugar beet. Weed Research 32: 451-463

Malaslı Z M (2010). Şeker pancarı üretim alanlarında yabanc1 otla mücadele yöntemleri ve uygulama etkinliklerinin belirlenmesi. Yüksek lisans tezi, Harran Üniversitesi Fen Bilimleri Enstitüsü (Basılmamış), Şanlıurfa

Marwitz A, Ladewig E \& Marlander B (2014). Response of soil biological activity to common herbicide strategies in sugar beet cultivation. European Journal of Agronomy 54: 97-106

Mobarak O M M A (2013). Determination of critical period of weed competition with sugar beet (Beta vulgaris L.) and weed control. PhD Thesis. Assiut University (Unpublished), Egypt

Norris R F (1996). Sugar beet integrated weed management. Publication UC IPM Pest Management Guidelines: Sugar beet, Veg Crops/Weed Science, UC Davis UC DANR Publication 3339

Parthasarathi T, Velu G \& Jeyakumar P (2013). Impact of crop heat units on growth and developmental physiology of future crop production. Research \& Reviews: A Journal of Crop Science and Technology 2(1): 1-11

Salehi F, Esfandiari H \& Mashhadi H R (2006). Critical period of weed control in sugar beet in Shahrekord Region. Iranian Journal of Weed Science 2: 1-12

Swanton C J \& Weise S F (1991). Integrated weed management: The rationale and approach. Weed Technology 5: 657-663

Tursun N, Akinci I E, Uludag A, Pamukoglu Z \& Gozcu D (2012). Critical period for weed control in direct seeded red pepper (Capsicum annum L.). Weed Biology and Management 12: 109-115

Young S L (2012). True integrated weed management. Weed Research 52: 107-111 